\title{
Eugen Bacon
}

\section{Journaling - a path to exegesis in creative research}

\begin{abstract}
Despite the relatively recent debate that unfolds in Special Issue 14 of TEXT, practice-led research remains a reasonably vexed topic. Writer and academic Scott Brook shares in his introduction of that special issue how, at a session on practice-led research, he noticed 'a clear distinction was established between discussions aimed at establishing the legitimacy of creative works as research, and discussions on how artists in the university can establish a "research practice"' (Brook 2012). Biggs and Büchler continue this debate with examples of similar development overseas, where even conformism to the conventions of academic research may not have impactful outcomes for the artists (Biggs \& Büchler 2012). This is because, as Biggs and Büchler suggest, research outputs inclined to follow academia may not be relevant or important to the wider community. Exegesis in practice-led research positions itself between the creative work and the audience in that it frames practice. But where is the practitioner who is both an artist and academic positioned? Exegesis helps answer this question by encouraging the practitioner to establish their own research practice, where creative practice continues to play its dynamic role. When practice-led research outputs comprise a creative artefact and an exegesis, it is crucial for the practitioner to adopt journaling to capture evidence of a self that evolves with practice and the research.
\end{abstract}

Key words: creative research, journaling, exegesis

\section{Introduction}

Some writers keep journals; I keep scraps. These require more structuring (my nemesis) to generate into a workable journal of reflexive activities that shape and drive the artefact; that is a practical approach for a writer like me with a fluid writing practice, an adventurous one that sustains expeditions and explorations as a writer.

Far from untreated adolescent musings on abandoned love, those rambling monologues and angst-filled thought bubbles scrawled in lipstick, tears and ink in that long-ago diary of mine, the academic journal steers my already existent scrapping. Hand-scribbles of sometimes illegible writing speckled with ideas, dialogue and fragments of characterisation. These scraps grow into dog-eared piles in my handbag, by my bedside, beneath my workstation ... before I transcribe them into a computer database. (Bacon 2013)

This paper will argue that the journal is more than an instrument for whimsical entry, for nonreflexive anecdotes; it is a flexible instrument of personal and scholarly insights. Journaling informs the mapping of self and research. It does so through an intuitive, albeit reflexive, experience, where intuitive refers to discerning, not just something based on feelings rather than facts or evidence, and reflexive means inward reflection, something that is focussed on improving 'self' and 'process'. Reflexivity thus becomes the bridge, the element that invites the practitioner's crossing between the creative artefact and the exegesis. The writer of the journal may document something to use or reference as a creative agent, something to help decode and recode the process of learning. As a manageable capture of the contextual experience, journaling helps the creative researcher validate creative praxis and product. It 


\section{Eugen Bacon TEXT Vol 18 No 2}

allows the practitioner to prove - by way of refined exegesis - how context is explored, challenges are anticipated, complexity is interrogated and answers to the research questions are deduced.

Months ago, the opening meeting with my $\mathrm{PhD}$ supervisor proved instructive. I was approaching the research like a fledgling. It was time to unpack those university lectures and wrap on a research mantle. Time to craft my own - not my lecturers' - bibliography. I was initiating my research with multiple questions. The supervisor asked: 'What is the common theme that binds these questions?' I blinked. 'What theoretical frameworks apply to your writing?' I looked for an answer. Then she asked: 'Have you started journaling to inform your exegesis?' I broke out with a muttered assertion of having started a journal and, as my words petered to a silence that my supervisor filled, she encouraged me to consider not one, not two but possibly three journals. Three? I laughed. What did one need three journals for? Already there was one ... well ... a somewhat journal. When undertaking a PhD by artefact and exegesis, I then understood, it was elementary to document reflexive activity. Undeniably, I had made unquestionable progress in moving to an orderly mess in the form of a spreadsheet, from my earlier 'scrapping', seen in Figure 1:

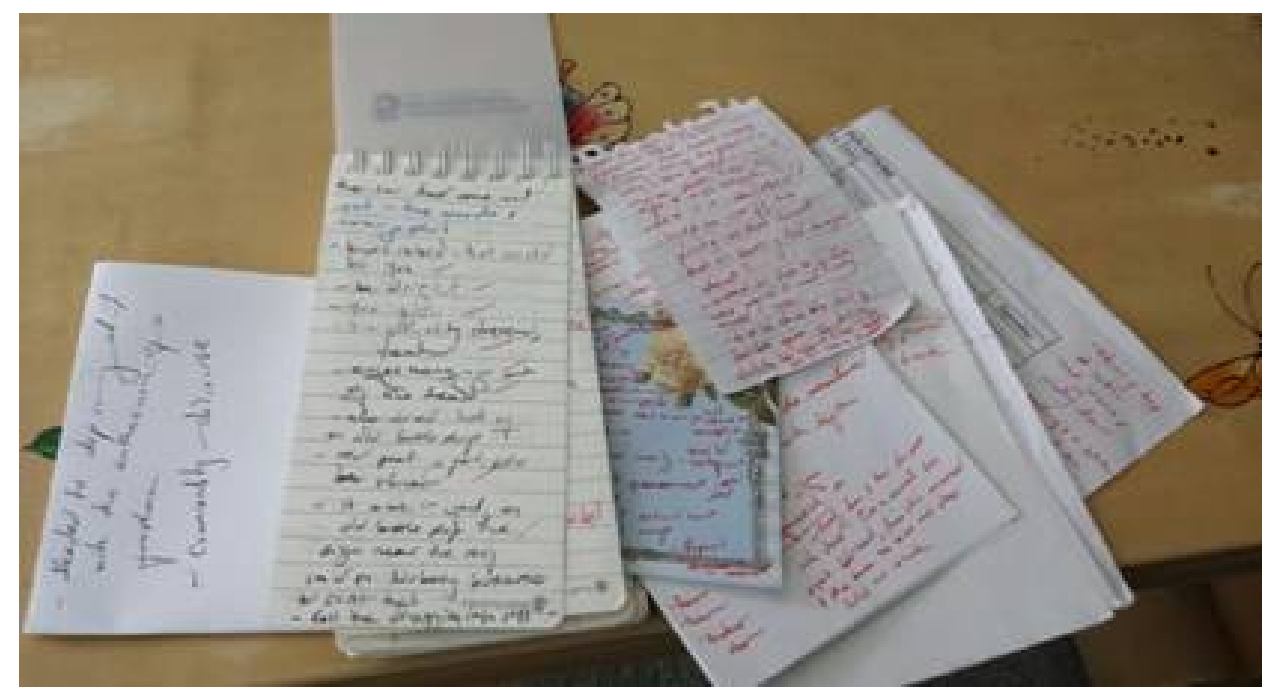

Figure 1: Unkempt scraps

The supervisor hinted at various types including but not limited to an academic journal and a cathartic journal. Somewhere in the haze of unfiltered thoughts, as I mentally unscrambled the logic or illogic of this new knowledge, the supervisor was saying, '... that is why we do not start writing the exegesis with an introduction'.

A time later when I shared that I had documented our first meeting, the supervisor smiled and moved to reassure me that I did not need to keep all three journals. But I had already committed myself to the practice of journaling in three modes; had found value in the triangulation of these modes from which an exegesis would emerge. Firstly, in those early stages of research when I was floundering, uncovering process and self, I sought the cathartic journal to find voice, cast insight to my anxiety and discover a 'self in process'. Then, as I explored each argument and developed scholarly literature to support it, the academic journal became a worthy record of fertile links. Finally, the literary journal housed excerpts of literary writing from relevant writers.

Consequently, I began to value journaling - not simply as a 'database' but as a means to validate the creative research. In the provoking space of practice-led research, a creative practitioner must establish scholarly contribution to knowledge. Jane Messer acknowledges the diverse skills and interests of artists who, in interdisciplinary art faculties in academia, must strive towards depicting their work as relevant institutional research (Messer 2012: 2). Shane Strange discusses the creative researcher whose practical activity must generate knowledge despite uncertain outcomes, the subjective interpreting of those outcomes and the contingency of creative practice (Strange 2012: 3). As Lelia Green writes, practice-led research is complex. For scholarly recognition, it must be 
- subject to its own standards of rigour and validity;

- assessable according to judgements of 'good' and 'bad';

- experiential and qualitative;

- non-quantifiable;

- the only methodology available through which to pursue some research questions. (Green 2007: 1-2)

Supporting this debate on the intricacy of practice-led research, Holbrook et al look at diversity of exegeses in the Australian content and the expectations a candidate brings in the process of learning and development. Practice-based research

requires candidates to engage in a dialogue between their art-making practices and their conceptual thinking about art as research, and yet candidates tend to be more familiar with the expectations of art-making and less with the academic expectations associated with doctoral study. (Holbrook et al 2013: 5)

In the quest for recognition, for placement alongside researchers in scientific disciplines that support quantitative studies, a creative practitioner in practice-led research must be able to demonstrate rigour and validity, where the duration of the research and the consolidated body of knowledge arising out of it become practicable elements of substantiation.

Jen Webb, in her article 'The logic of practice? Art, the academy, and fish out of water', explores a 'wicked problem': how to be both artist and academic; how to produce both art and knowledge products (Webb 2012: 2-3). Subtle differences exist between an artist and a scholar, and the practitioner who must be both is caught in two fields that 'cannot exist in the same space; and yet they must co-exist' (Webb 2012: 8-9). Webb and Donna Lee Brien together address the perception of art as an inferior type of knowledge in the academy, or as not belonging (Webb \& Brien 2008: 1). This perception is fraught because to prove otherwise one must prove what it means to generate knowledge through creative art. Webb and Brien argue that, traditionally, knowledge generated by art and the interpretation of that knowledge is cloaked in reviews and critical writing (2008: 3). This opposes research in the sciences, social sciences and humanities where one searches what can be seen, demonstrated, argued (2008: 3). Knowledge and interpretation in arts is often located within the artist. But the artist in practiceled research is still finding answers, 'is not confident he or she already knows, or even that knowledge can ever be full or final' (2008: 3). The truth value is still an unknown because knowledge is produced 'retroactively'; it is something that arrives in a retrospective way. The diversity of practitioner disciplines and the variety of their individual artefacts (novels, biographies, plays, paintings, sculptures ...) add complexity to the process of determining the integrity of an individual work along scholarly discourse. Furthermore, Webb and Brien point out that practitioners continue to identify their contribution in terms of publishing advances, book sales or literary awards, rather than knowledge production or interpretation (2008: 11).

To substantiate the production of knowledge in creative research, and find recognition, the practitioner must document. Data collection or documentation is a familiar process to the researcher, any researcher. Julia Colyar in Becoming Writing, Becoming Writers surveys the qualitative researcher's puzzle of how to write more engagingly, more communicatively. She examines the writing process and positions writing as a learning tool. Placeholder notes in her own writing - notes such as 'I need a quote' or 'problem statement here' (Colyar 2009: 421) function as roadmaps or false beginnings that will lead to the real article she means to write. She is able to move from experimentation to forging a discussion, building certainty, finding direction ... concluding in earnest a given topic.

In similar experimentation, the practice-led researcher may use a journal as a method of inquiry, a placeholder for questions and investigations essential to the research; excerpts or bibliographies that will initiate or corroborate discussion, find or set direction, layer certainty into the research.

While my first attitude to journaling was that of a sceptic, my use of the cathartic (or spontaneous) journal now offers a retreat where I can speak to a sense of urgency and, through intuitive reflection, share an easy intimacy with the self and process. With this journal, I train myself to be patient with the research process, with the journey; to break ideas down, make them accessible. I write in the journal to frame my thinking and to encounter a self in process, an evolving voice. Sometimes the journal reflects back my thoughts: 'relax, don't make knee 
jerk statements; challenging thoughts like: For what? Then why? But when? Or goading thoughts like: That's ridiculous!' 'That's articulate!'

\section{Exegesis, a being}

The scholarly-artist writes, keeps record, to substantiate, make visible, communicate their knowing. Colyar notes how writing is generative; it is being creative in multiple ways. It summons the learning modes of doing, depicting, symbolising. 'Each of these modes is active; each locates learning in a different place: The hand, the eye, and the brain' (Colyar 2009: 426). So we can argue that the journal stimulates the exegesis, stimulates the creation in the research, and vice versa, because:

One cannot be passive and at the same time generate words, sentences and paragraphs. (Fulwiler cited in Colyar 2009: 426)

The journal, like my hitherto scrapping, hand-scribbles of sometimes illegible writing speckled with ideas, dialogue, fragments of characterisation ... captures the goal, the plan, the translation, revision (repeat). Tomlinson (cited in Colyar 2009: 426) suggests the writing process involves 'holding' ideas. In generating text as written in a journal I am 'holding' ideas. Later, I may access connected ideas and polish them, associate them with learning, with forming, with finding answers to research questions.

\section{Up at stupid o'clock, nightie on backwards. Urge to write.}

This is an entry in my cathartic journal. How does this dialogic engagement with the self inform an exegesis, the goal of which is to 'validate' creative praxis and product? Should it matter that the analysis, assessment, self-interrogation is in its purest form? Am I gaining or losing? - this is a question I must ask myself. Let's take the journal entry as a placeholder, a 'meaning to follow'. It is raw as an entry but might connect to more inference. If the exegesis is a deliverable in practice-led research, what exactly is an exegesis?

Thesaurus.com defines exegesis as 'analysis', 'explanation', 'exposition' (Thesaurus.com 2014). Jeri Kroll looks it up in the Oxford English Dictionary and finds that it derives from the Greek meaning 'to interpret, guide and lead' (Kroll 2004). The fifth edition of the Macquarie

Dictionary calls it a 'critical explanation', 'interpretation' (Macquarie Dictionary 2009: 579). So we anticipate an exegesis will help something add up, will bring sense.

In practice-led research, an exegesis is that dissertation that accompanies a creative artefact; it is the written component that speaks to production of knowledge. Its application often takes place in what Barbara Milech and Ann Schilo term the 'research-question model' (Milech \& Schilo 2004). Unlike the 'context model' where the exegesis gives context (historical, social or disciplinary) for the creative production or the 'commentary model' where the exegesis is a comment (i.e. a research report describing process) on the creative production, the Milech and Schilo's research-question model 'hinges on a research question posed, refined and reposed by the student across the several stages of a research program' (Milech \& Schilo 2004). In this model, the exegesis and creative production are independent but associated components that inform each other.

Exegesis is both a product and a process. It implies reflexivity that will shape, substantiate, make connections between creating art and showing research gains. If only to go with the grains of orthodox academic research, exegesis is the dissertation that makes plausible, that constitutes, the creative research as scholarly work. Paul Magee argues against this conformism:

Why ignore these traditions of collegial evaluation, to insist that an art work's contribution to knowledge can only be judged if it comes with a load of that artist's words as well? (Magee 2012: 3)

But even if a candidate resists conformity, their work will find its way to academic gatekeepers who must endorse the creative research as having met the requisites of a $\mathrm{PhD}$. So there is inevitability in the exegesis. Krauth sees exegesis in academic higher degrees as constituting a 'framing device' that positions itself between the work and the audience, 'creating a link between the creative work, its milieu of production, and the broader field into which it is 
projected' (Krauth 2002). Exegesis makes logic of the creative artefact, and vice versa. The exegesis convinces the academy, if not the practitioner, about the purpose and the value of the research.

Writing this decisive exegesis is no easy feat for the practitioner who is playing dual roles of the artist and the intellectual. Jeri Kroll understands this type of quandary:

The new type of higher degree thesis that requires self-reflexivity, creativity and experimentation as well as scholarship is a fascinating hybrid creature with a claw firmly embedded in two bodies - the arts and academia. (Kroll 2004)

Kroll cites Irish avant-garde playwright, poet and novelist Samuel Beckett: 'The writer is like a foetus trying to do gymnastics' (Kroll 2004) to support her view that self-reflexivity as a way of thinking does not come naturally to everyone. So a routine, such as journaling, coaches the hitherto disinclined practitioner towards a self-learning philosophy that is workable for them in the context of creative research.

When a practitioner learns to adopt journaling, apply and embrace it even, entries such as my 'Up at stupid o'clock...' remain nothing but coy, emotive. Such entries are ad hoc, spontaneous, eccentric ... akin to Colyar's nonsense words, 'finkle and whateverness' (Colyar 2009: 422), those placeholder notes. Of what use are these entries if they find place in my exegesis which other scholars expect to use to interrogate my practice? A specific journal entry of mine shifts from non-reflexive to reflexive when I learn to transform it to a scholarly insight, analysis or activity: 'Read Northumbria's Tony Williams 'Iterations: Days, walks, episodes, chapters, scenes' (Williams 2013).' (Bacon 2014) In this example, I am linking the journal entry to the immersive experience of another writer, one whose critical and imaginative thinking takes place in his everyday. In doing so, I have transformed the journal entry from finkle and whateverness to an intuitive, albeit reflexive response as a writer and a researcher. I have captured the moment, understood it to be the immersive experience of the autoethnographer. I have identified that my waking up at stupid o'clock occurs because my self-experiences as a practitioner and a researcher, as an autoethnographer in practice-led research, weave into my night-time; that creative research accompanies my everyday, thus my time is never idle.

With this reflexive activity the entry begins to display attentiveness to not only my own 'model of writing, but those of other writers and thinkers' (Bourke \& Nielsen 2004: 3), writers such as Williams who shares how, in his immersive experience, writing invades his 'everyday' (Williams 2013). Now I can translate it to the exegesis. Unlike a memoir or some anecdotal account of my writerly life, it becomes what Bourke and Nielsen consider 'a conscious and well-articulated awareness of the research practices in evidence in the creative work' (Bourke \& Nielsen 2004: 4).

To reiterate, nestled in this research with my exegesis are the three journals: a literary journal that integrates excerpts from influencing authors; an academic journal that contains bibliography referencing on discourse, process, critical and cultural theories; and the cathartic journal that features insights. The cathartic journal is what Bourke and Nielsen refer to as a first order journal, relevant only to me, 'primarily concerned with the emotional relationship of the writer to the task of writing, or to the subject of the writing' (Bourke \& Nielsen 2007: 2).

In examining the writing process, Colyar positions writing as a learning tool which enables researchers to know about themselves and their topics: 'Writing is not simply what we "do", but also how we become better writers and scholars' (Colyar 2009: 421).

I reflect upon and scrutinise my practice-led research, applying intuition, attention, experimentation and new techniques to find new learnings. And what do you know? - I just might discover with animation or panic that the very research questions themselves have become stronger, diluted or transformed. (Bacon 2013)

How am I best equipped to determine what Robyn Stewart suggests in her paper on constructing models for practitioner-based research that 'the underlying structures need a base that is informed, purposeful, rigorous and ethical' (Stewart 2000)? Having identified my own topic, posed my own questions and worked out (continually working out) hypotheses and processes through practice-led research, journaling helps me speak to that animation, that 
panic. Philip McIntyre suggests that reflection on patterns of action, on situations in which the practitioner is creating 'can lead to real knowledge - knowledge that is verifiably true' (McIntyre 2006: 6). Insightful reflection reveals understandings and becomes a source of truth about the creative process. To the creative researcher who is also an auto-ethnographer, journaling captures reflexive activity and gives data for analysis. It allows a systematic exposure to 'the actions, the second sense, the feel, the tacit knowing that a creative practitioner utilises in practice' (Burgess cited in McIntyre 2006: 6). Whether journaling is through a single journal or several journals with distinct purposes, the activity allows the practitioner to have a flexible ensemble of working practice, critical reflection and research data, a documentable ensemble that consequently substantiates research.

Journaling gives me a portrait by kick-starting the analytical gaze at self and process. The portrait is a reflection of the self and the evolving self, as I invent and re-invent myself. It is a placebo for the writing process, tricking me through false starts into creating. It costumes the research so that, like Colyar's non-introduction, I am not facing the blank screen. It is a control - the cathartic journal especially - reminding me that writing is process and product; it is the gauge of 'how are we feeling today?' What progress have we made so far? Journaling is a manageable capture of the contextual experience. To my unstructured self, it is a necessary 'evil' in a place where art and writing are 'two different ways of reaching for truth (Papastergiadis cited in Milech \& Schilo 2004); where practitioners shaping a PhD by artefact and exegesis may emerge as "Solomonic: they divide the "baby" in half, but do not indicate how the baby might live as a whole' (Milech \& Schilo 2004). First order journaling gives the exegesis a voice, encourages it to elaborate, elucidate, contextualise. It allows the exegesis to tell 'the story of the research' (Mann \& Fletcher cited in Milech \& Schilo 2004).

Second order journaling refines initial journal entries to something nearly worthy of publishable output in the form of an exegesis. It uses each respective journal as a creative agent to decode and recode each process and territory of learning. As I shape the research story - my thoughts better compartmentalised - I can ask myself in different ways, at different points, during progress or regress, what questions I mean to uncover, how I am tracking. I can map my footsteps along candidacy to examination, a chart that feeds into the exegesis - the second order journal that amalgamates, informs, positions, supports and complements the artefact. And as Colyar understands, it is the finkle and whateverness connected with everything else that will give me a coming to understandings, re-written (Colyar 2009: 423).

Exegesis is a knowing, is a refinement of Bourke and Nielsen's second order journal, 'engaging as it does not only with the moment of writing, but the moments between writing the ongoing, reflective, critical and analytical learning process of 'being a writer' (Bourke \& Nielsen 2007: 3). It materialises discourse, where the practitioner whose creative artefact is a novel, perhaps, writes about writing in a self-conscious, evaluative, critical way. As Bourke and Nielsen affirm, other writers who wish to understand, to find answers to those questions about process, product, praxis and practice, can draw upon this very exegesis (Bourke \& Nielsen 2007: 3).

\section{Conclusion}

To conclude, this paper looks at how evidence of my creative practice (journal(s), exegesis and creative artefact) is core to my creative research. Applying journaling to inform exegesis, I find truth in Robyn Stewart's claim about practitioner-based research: that 'It is important to learn to step back and critically analyse situations, to recognise and avoid bias, to discover processes to obtain valid and reliable data and to think abstractly' (Stewart 2000). An exegesis frames, interprets, and defines the creative artefact. In 'an institutional setting that valorises peer reviewed and publicly verifiable research this report, or exegesis' provides one part of a whole; it gives space for academic analysis and exposes that knowledge is obtained through reflective practice (McIntyre 2006: 8). While amenable to anticipations of the academy, exegesis also helps me. In it, I articulate what I know, chart my false starts and real starts. With each start real or false and kaleidoscopic in this form of action research that applies an iterative cycle of action and reflection - I am exploring, anticipating, interrogating, deducing. Together, the exegesis and creative artefact shape my pursuit to "explore the questions opened up by the work itself' (Webb \& Brien 2008: 8). They help me find answers that are 'not simply experimental, but again personal, political, and intellectual, reflecting the qualitative effort 
toward more engaging, more useful texts that "change minds and hearts" as well as the norms of academic writing' (Foley cited in Colyar 2009: 424).

\section{Works cited}

Bacon, E 2013 'Writerly passage: Crafting stories within a story', BukkerTillibul 7: http://bukkertillibul.net/Text.html?VOL=7\&INDEX=17 (accessed 27 December 2013) return to text

Biggs, M \& D Büchler 2012 'Postscript', TEXT Special Issue 14:

http://www.textjournal.com.au/speciss/issue14/Biggs\&Buechler.pdf return to text

Bourke, NA \& PM Nielsen 2004 'The problem of the exegesis in creative writing higher degrees', TEXT Special Issue 3: http://eprints.qut.edu.au/4598/1/4598_1.pdf (accessed 21 January 2014) return to text

Brook, S 2012 'Introduction. Part 2: The critiques of practice-led research', TEXT Special Issue 14: http://www.textjournal.com.au/speciss/issue14/Brook\%20(Intro\%202).pdf (accessed 1 August 2014) return to text

Colyar, J 2009 'Becoming writing, becoming writers', Qualitative Inquiry 15, 2 (February) 2009: 421-436 http://qix.sagepub.com/content/15/2/421 (accessed 29 December 2013) return to text

Green, L 2007 'Recognising practice-led research ... at last!', Hatched 07 Arts Research Symposium: http://www.pica.org.au/downloads/141/L_Green.pdf (accessed 12 January 2014) return to text

Holbrook, A, B Simmons, J Scevak \& J Budd 2013 'Initial expectations in fine art', TEXT Special Issue 22: http://www.textjournal.com.au/speciss/issue22/Holbrook_et_al.pdf (accessed 6 January 2014) return to text

Krauth, N 2002 'The Preface as Exegesis', TEXT 6, 1:

http://www.textjournal.com.au/april02/krauth.htm (accessed 25 October 2014) return to text

Kroll, J 2004 'The Role of the Examiner: Scholar, reviewer, critic, judge, mentor,' TEXT 8, 2: http://www.textjournal.com.au/oct04/kroll.htm (accessed 21 January 2014) return to text

Macquarie Dictionary 2009 5th edn, Macquarie Dictionary Publishers, Sydney return to text

Magee, P 2012 'Introduction. Part 1: Beyond accountability?', TEXT Special Issue 14: http://www.textjournal.com.au/speciss/issue14/Magee\%20(Intro\%201).pdf (accessed 1 August 2014) return to text

McIntyre, P 2006 'Creative practice as research: "Testing out" the systems model of creativity through practitioner based enquiry', Speculation and Innovation: applying practice led research in the Creative Industries, University of Brighton, Arts and Humanities:

http://arts.brighton.ac.uk/_data/assets/pdf_file/0019/43093/McintyreP.pdf (accessed 22 August 2014) return to text

Messer, J 2012 'Practising interdisciplinarity', TEXT Special Issue 14:

http://www.textjournal.com.au/speciss/issue14/Messer.pdf (accessed 22 August 2014) return to text

Milech, BH \& A Schilo 2004 'Exit Jesus': Relating the exegesis and creative/production components of a research thesis', TEXT Special Issue 3:

http://www.textjournal.com.au/speciss/issue3/milechschilo.htm (accessed 21 January 2014) return to text

Stewart, R 2001 'Practice vs Praxis: Constructing models for practitioner-based research', TEXT 5, 2: http://www.textjournal.com.au/oct01/stewart.htm (accessed 19 January 2014) return to text 
Strange, S 2012 ‘Creative research: A radical subjectivity?’ TEXT Special Issue 14: http://www.textjournal.com.au/speciss/issue14/Strange.pdf (accessed 22 August 2014) return to text

Thesaurus.com 2014 'Exegesis': http://thesaurus.com/browse/exegesis (accessed 22 January 2014) return to text

Webb, J 2012 'The logic of practice? Art, the academy, and fish out of water', TEXT Special Issue 14: http://www.textjournal.com.au/speciss/issue14/Webb.pdf (accessed 1 August 2014) return to text

Webb, J \& DL Brien 2008 “"Agnostic” thinking: Creative writing as practice-led research', Working Papers in Art and Design

5:https://www.herts.ac.uk/_data/assets/pdf_file/0014/12434/WPIAAD_vol5_webb_obrien.pdf (accessed 22 August 2014) return to text

Williams, T 2013 'Iterations: Days, walks, episodes, chapters, scenes', TEXT 17, 2:

http://www.textjournal.com.au/oct13/williams.htm (accessed 6 January 2014) return to text

Eugen Bacon studied at Maritime Campus - Greenwich University, UK, less than two minutes' walk from The Royal Observatory of the Greenwich Meridian. Her arty muse fostered itself within the baroque setting of the Old Royal Naval College, and Eugen found herself a computer graduate mentally re-engineered into creative writing. She is now a PhD candidate in Writing by artefact and exegesis at Swinburne University of Technology.

TEXT

Vol 18 No 2 October 2014

http://www.textjournal.com.au

General Editor: Nigel Krauth. Editors: Kevin Brophy, Enza Gandolfo \& Linda Weste text@textjournal.com.au 